\title{
BENTUK PENYAJIAN TARI KREASI CANGKLAK DI SANGGAR RAMPOE BANDA ACEH
}

\author{
Novirela Minang Sari \\ Fakultas Keguruan Ilmu Pendidikan Sendratasik \\ Universitas Syiah Kuala Banda Aceh \\ e-mail : novirelaminangsari91@gmail.com
}

Diterima : 16 Maret 2019. Disetujui : 9 Mei 2019. Dipublikasikan : 30 Juni 2019

(C2019 - DESKOVI Universitas Maarif Hasyim Latif. Ini adalah artikel dengan akses terbuka di bawah lisensi CC BY 4.0 (https://creativecommons.org/licenses/by/4.0/)

\begin{abstract}
ABSTRAK
Penelitian ini membahas tentang sebuah karya tari yang diciptakan di Sanggar Rampoe Kota Banda Aceh. Cangklak adalah salah satu tari kreasi yang sudah berkembang, akan tetapi masih mengikat pada pola tradisi. Oleh karena itu peneliti tertarik untuk mendeskripsikan bentuk penyajian dari tari kreasi Cangklak. Penelitian ini menggunakan metode deskriptif kualitatif guna mendapatkan data-data yang akurat serta memberikan pemahaman terkait dengan bentuk penyajian tari kreasi Cangklak di sanggar Rampoe Banda Aceh. Berdasarkan hasil penelitian terkait dengan bentuk penyajian, tari Cangklak diciptakan pada tahun 2006 oleh Yusri Sulaiman Skm, M. Kes. Tari ini menggunakan iringan musik, seperti rapai, geundrang, seurune kalee. Tari Cangklak adalah sebuah tari yang memvisualisasikan perempuan-perempuan Aceh dengan pesonanya. Gerak tarian yang energik menjadi khas dari tarian ini. Tari Cangklak ditarikan oleh enam orang penari perempuan, jumlah penari tersebut bisa disesuaikan dengan kebutuhan yang diinginkan atau keadaan pentas yang memiliki ruang besar atau kecil.
\end{abstract}

Kata kunci: bentuk penyajian, cangklak, tari kreasi

\section{ABSTRACT}

This research tells about an artwork that created at Sanggar Rampoe Banda Aceh. Cangklak is one of the creation dances has been improved but still based on the traditional dance of Aceh. Therefore researchers are interested in describing the presentation form of Cangklak dance creations. This study uses a qualitative descriptive method to obtain accurate data and provides an understanding related to the form of Cangklak creation dance in the Rampoe studio in Banda Aceh. Based on the results of the study related to the form of presentation, Cangklak dance was created in 2006 by Yusri Sulaiman Skm, M. Kes. This dance uses musical accompaniment, such as rapai, geundrang, seurune kalee. Cangklak dance is a dance that visualizes Acehnese women with their charms. The energetic dance moves are typical of this dance. Cangklak dance is danced by six female dancers, the number of dancers can be adjusted to the desired needs or stage conditions that have large or small spaces.

Keyword: Aesthetics, Music, Sestina

\section{PENDAHULUAN}

Aceh merupakan provinsi yang terletak di sebelah barat kepulauan Nusantara, yakni pulau Sumatra, Agama, pendidikan, dan adat, membuat Aceh dikenal sebagai provinsi yang diberi penghargaan istimewa. Keistimewaan adat dan budaya Aceh terlihat jelas dalam bentuk seni budaya. Seni dan budaya merupakan dua hal yang tidak dapat dipisahkan dalam kehidupan masyarakat. Kebudayaan Aceh yang sangat terlihat adalah adat, karena adat terdapat dalam hidup kemasyarakatan, keagamaan, perekonomian, dan dalam berkesenian.

Seni adalah ungkapan perasaan dan pengalaman batin manusia yang di komunikasikan melalui media tertentu yang bertujuan untuk mengungkapkan nilainilai kemanusiaan suatu kelompok masyarakat atau individu dalam memenuhi kebutuhan spritualnya.
Perkembangan dan kepopuleran tari sangat ditentukan oleh peran suatu lembaga masyarakat atau sanggar. Sanggar merupakan salah satu wadah masyarakat untuk memperkenalkan, mempelajari, mengasah, dan mengembangkan sebuah seni, dalam hal ini khususnya seni tari. Terdapat dua faktor yang mempengaruhi proses pembelajaran seni tari, yaitu faktor individu dan sosial. Hal ini sesuai dengan ungkapan yang tercantum dalam Depdiknas (2004: 12) yaitu Berhasil atau tidaknya sanggar dalam memperkenalkan tari kreasi baru kepada muridmuridnya tergantung kepada bermacam-macam faktor. Adapun faktor-faktor itu dapat dibedakan menjadi dua golongan

a) faktor individu mencakup kematangan / pertumbuhan, kecerdasan, latihan, motivasi dan pribadi,

b) faktor sosial mencakup dorongan keluarga, keaktifan sanggar dan sistem manajemennya. 
Uraian di atas menunjukkan bahwa sanggar bukan hanya sebagai wadah untuk belajar seni tari, tetapi juga tempat mengasah, mengolah dan menumbuhkan sikap kematangan, kecerdasan dan keterampilan berbagai macam seni budaya.

Tari tradisi merupakan tarian yang lahir dan berkembang dari kebiasaan-kebiasaan masyarakat pada zaman dahulu yang memiliki unsur-unsur keindahan dan mengandung makna tertentu yang selalu bertumpu pada pola-pola tradisi dan masih turun temurun, sedangkan tari kreasi ialah tarian yang dikembangkan berdasarkan kebebasan dalam pengungkapannya yang tidak lagi bertumpu pada pola-pola tradisi, Sindo (2006:23).

Ada juga tari kreasi yang sudah berkembang tetapi masih mengikat pada pola tradisi. Contohnya tari Cangklak yang ada pada Sanggar Rampoe Banda Aceh.

\section{METODE PENELITIAN}

Penelitian ini menggunakan pendekatan kualitatif didasarkan kepada rumusan masalah yang dikaji. "Teknik kualitatif adalah teknik yang dipakai jika penyajian data dan pembahasan hasil penelitian tidak didominasi oleh angka-angka", Azwardi (2012:30). Dari pendapat tersebut dapat disimpulkan bahwa pendekatan kualitatif artinya hasil penelitian ini tidak diolah secara matematika akan tetapi lebih kepada penyampaian perasaan atau wawasan yang datanya diambil berdasarkan sampel.

Adapun jenis penelitian ini menggunakan metode deskriptif. "Penelitian yang dimaksud untuk mengumpulkan informasi status. Suatu gejala yang ada yaitu keadaan gejala menurut apa adanya pada saat penelitian dilakukan", Arikunto (2006:309). Metode deskriptif kualitatif digunakan untuk mendapatkan data-data yang akurat serta memberikan pemahaman terkait dengan bentuk penyajian tari kreasi Cangklak di sanggar Rampoe Banda Aceh, agar data yang didapatkan lebih lengkap, terpercaya dan bermanfaat

\section{PEMBAHASAN}

Salah satu sanggar yang berperan aktif dalam proses pengembangan seni tari yang ada di Banda Aceh adalah Sanggar Rampoe. Sanggar ini terletak di Lamgugop Banda Aceh yang dikoordinator oleh Zulkifli. Sanggar Rampoe merupakan salah satu sanggar yang tergolong banyak memperkenalkan tari kreasi baru, salah satunya yaitu tari Cangklak. Cangklak berasal dari bahasa Aceh yang berarti centil. Tari Cangklak diciptakan pada tahun 2006 oleh Yusri Sulaiman Skm, M. Kes.

Tari ini menggunakan iringan musik, seperti rapai, geundrang, seurune kalee. Pada umumnya Tari Cangklak belum diketahui oleh masyarakat luas, bahkan masyarakat Banda Aceh sendiri banyak yang tidak mengetahui bentuk penyajian tari Cangklak., padahal tarian Cangklak sudah ditampilkan pada ajang nasional maupun internasional.
Menurut wawancara Yusri Sulaiman (koreografer sanggar Rampoe) Tari Cangklak adalah sebuah tari yang memvisualisasikan perempuanperempuan Aceh dengan pesonanya. Gerak tarian yang energik menjadi khas dari tarian ini. Tari Cangklak ditarikan oleh enam orang penari putri, jumlah penari tersebut bisa disesuaikan dengan kebutuhan yang diinginkan atau keadaan pentas yang memiliki ruang besar atau kecil.

Gerak yang terdapat di dalam tari Cangklak adalah gerak-gerak yang dikembangkan dari pola-pola gerak tradisi Aceh. Busana yang digunakan dalam tarian ini merupakan pakaian Aceh yang sudah dimodifikasi. Salah satu keunikan yang dimiliki tari Cangklak adalah properti yang digunakan ada empat macam, yaitu sapu tangan, gelang kaki, kipas, dan payung.

\section{Bentuk penyajian tari kreasi Cangklak}

Berdasarkan hasil wawancara Cut Hasrina (penari generasi pertama tari Cangklak) 03 Mei 2014 pukul 16.00 wib bahwa tari kreasi Cangklak dipergelarkan pada saat acara-acara besar yang mayoritasnya di dalam sebuah gedung, dan ditarikan oleh enam orang penari wanita. Pada awal, pertengahan dan akhir tarian terdapat syair. Pada awal tarian tidak menggunakan musik tetapi hanya syair saja. Gerak pada tari Cangklak sangat bervariasi, karena terdapat beberapa gerak yang dikembangkan dari dasar gerak Aceh dan Melayu.

Berdasarkan hasil wawancara Rina Dwinanda 03 Mei 2014 pukul 16.00 selaku penari senior dan sekaligus merangkap sebagai pelatih serta terbukti pada saat melakukan observasi bahwa bentuk penyajian tari kreasi Cangklak terdiri dari "gerak, pola lantai, tata busana, tata rias, musik pengiring, properti dan pentas (panggung)".

\section{Sejarah tari Cangklak}

Proses ide awal tari Cangklak bermula dari keinginan koreografer Sanggar Rampoe untuk membuat karya tari kreasi dengan ide garapan ingin mengangkat sisi lain dari karakter wanita Aceh, yang pada dasarnya wanita Aceh itu bersikap tegas, tegar, dan konsisten. Namun demikian wanita manapun juga tetap memiliki sifat dasar kewanitaan, antara lain lemah lembut, penyabar, serta hal yang membuat mereka terlihat lebih cantik dan menarik yaitu berdandan.

Pemilihan judul karya Cangklak lebih fokus ditunjukan oleh koreografer untuk mengangkat sifat dasar kewanitaan tersebut yang juga menggambarkan sikap centil tentunya. Mengingat karya-karya yang ada selama ini selalu menginterpretasikan wanita Aceh identik dengan sikap tegas, dan konsisten. Untuk memenuhi ruang kreatifitas, koreografer berusaha untuk menghadirkan karya tari yang bernuansa sedikit berbeda dari karya-karya sebelumnya, serta tidak keluar dari koridor kepatutan akan nilai-nilai budaya yang dijunjung oleh masyarakat Aceh yaitu norma dan etika. 
Berdasarkan hasil wawancara dengan Yusri Sulaiman (Koreografer sanggar Rampoe) Tari Cangklak diciptakan pada tahun 2006 oleh Yusri Sulaiman, Skm, M.Kes. Tari Cangklak memvisualisasikan wanita-wanita aceh dengan pesonanya. Tari ini mencoba menyatukan unsur-unsur yang ada di Aceh, dengan properti yang lazim digunakan oleh wanita, seperti payung, kipas, gelang kaki, dan sapu tangan. Tari ini ditarikan oleh enam penari wanita dan tari Cangklak hanya mengedepankan sisi pertunjukan dan hiburan semata.

\section{Gerak Tari Cangklak}

Berdasarkan wawancara (05 Mei 2014) pukul 16.00 wib bersama Rina dwinanda selaku penari senior bahwa gerak pada tari kreasi Cangklak dimulai dari awal gerak masuk sampai dengan gerakan pulang. Pelaksanaan tari kreasi Cangklak di sanggar Rampoe dapat dilakukan di ruang tertutup ataupun di ruang terbuka. Tetapi pada saat dokumentasi pada bagian pengambilan proses gerak dilakukan di ruangan terbuka, dengan alasan menyesuaikan tempat yang ada.

Tarian ini menggambarkan tarian yang menunjukan keindahan semata dan hanya menggambarkan sisi pertunjukan saja. Ragam gerak yang terdapat pada tari ini tidak sederhana, karena tidak terdapat pengulangan-pengulangan di setiap gerakan. Tari kreasi Cangklak ini menggunakan empat properti, yaitu : Payung, Kipas dan Gelang Kaki.

Pada saat dokumentasi untuk melakukan seluruh proses gerak yang ada di dalam tarian ini, dilakukan oleh enam orang penari. Pada tahap tertentu ada yang dilakukan oleh tiga penari saja, karena sisa tiga penari lainnya keluar untuk meletakkan properti yang satu dan mengambil properti yang lainnya. Pada awal masuk diiringi oleh syair Aceh. Syair pada gerak masuk :

\section{Meukatem that putroe \\ Ngon payong bak jaroe \\ Jimeuputa ceudah lagoinaa \\ Jimeudoda yam e laa laa \\ Mu eatoe langkah}

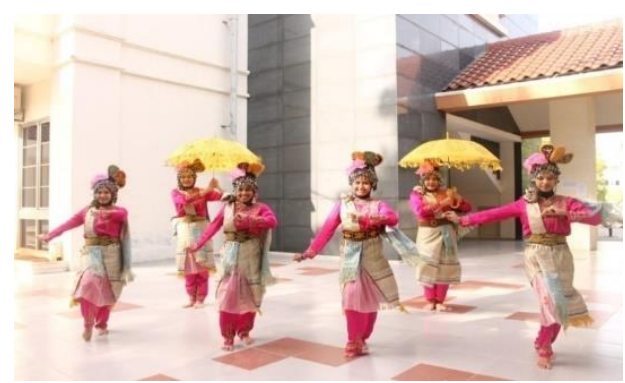

Gambar 1. Gerak bergantian

(Sumber: Novirela Minang Sari, 2014)

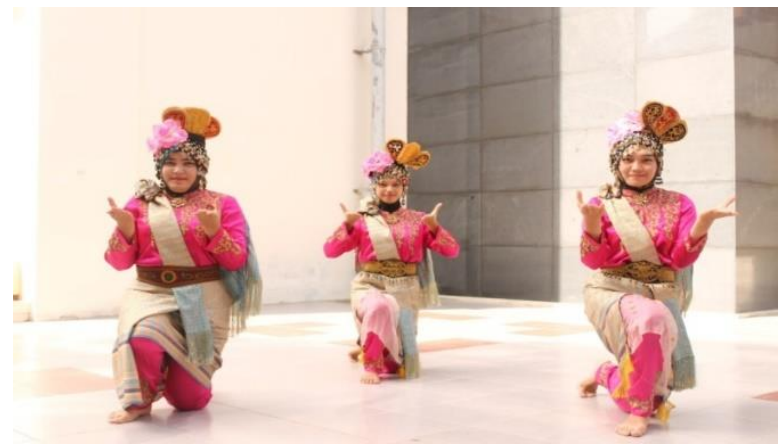

Gambar 2.Gerak Tanpa Properti

(Sumber: Novirela Minang Sari, 2014)

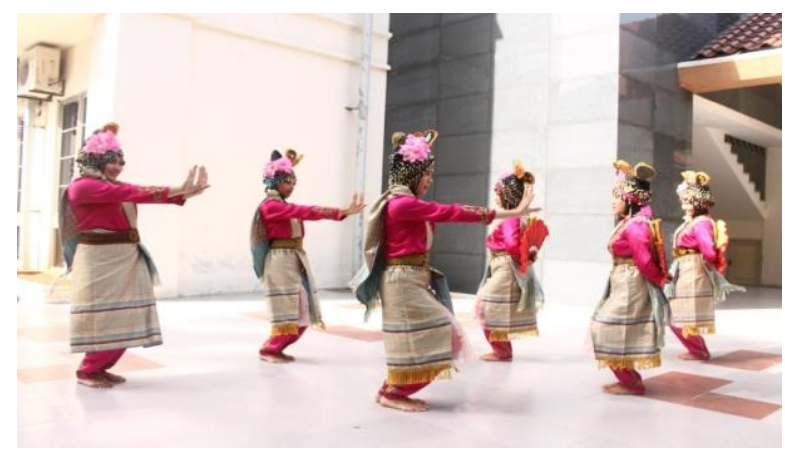

Gambar 3. Gerak Keluar Masuk

(Sumber: Novirela Minang Sari, 2014)

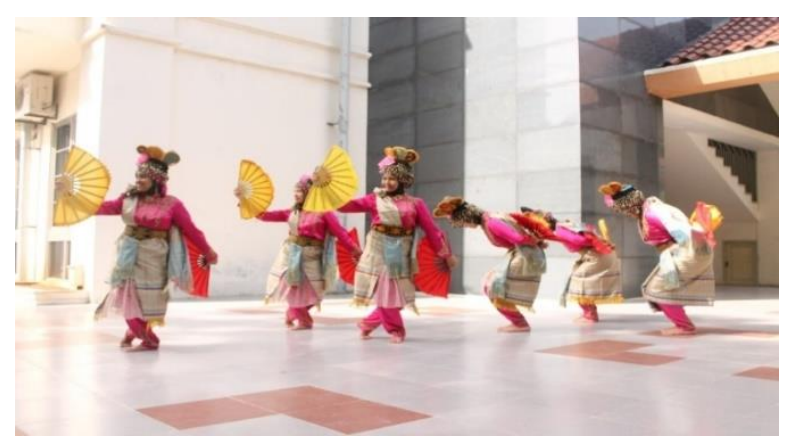

Gambar 4. Gerak Membuka Kipas

(Sumber: Novirela Minang Sari, 2014)

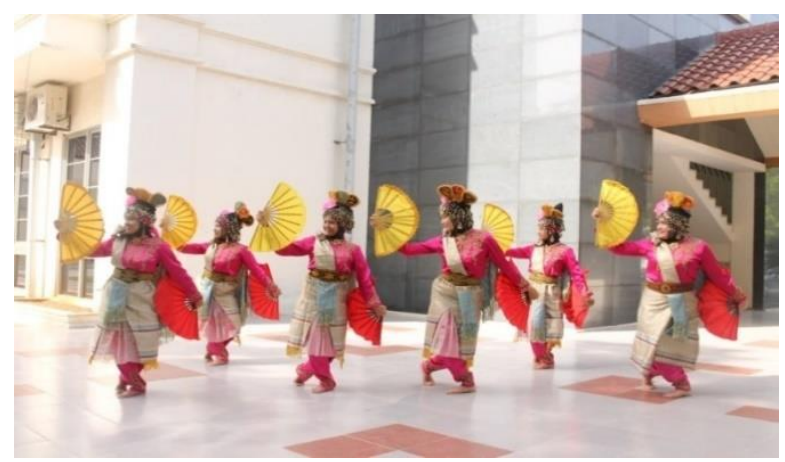

Gambar 5. Gerak Membuka Kipas Bersama (Sumber: Novirela Minang Sari, 2014) 


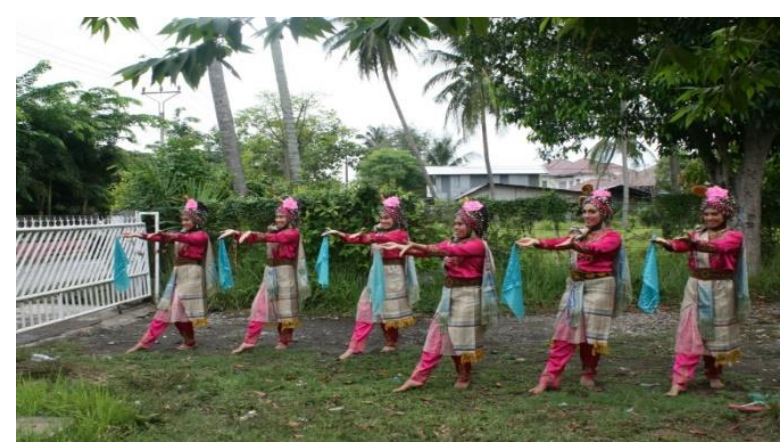

Gambar 6. Gerak Memainkan Sapu Tangan (Sumber: Novirela Minang Sari, 2014)

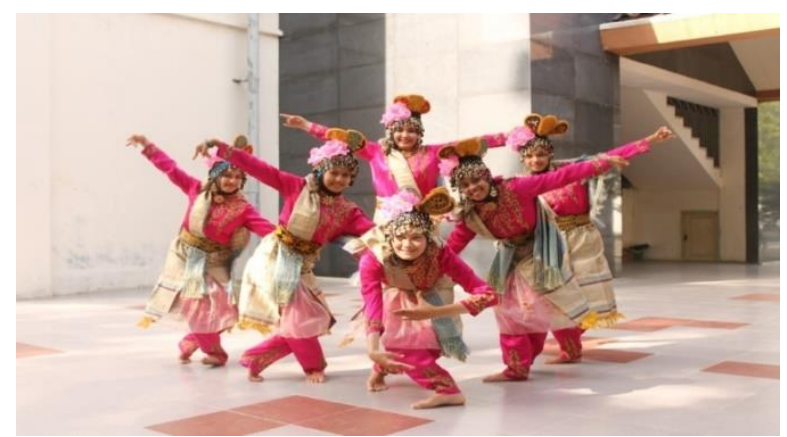

Gambar 7. Gerak Habis

(Sumber: Novirela Minang Sari, 2014)

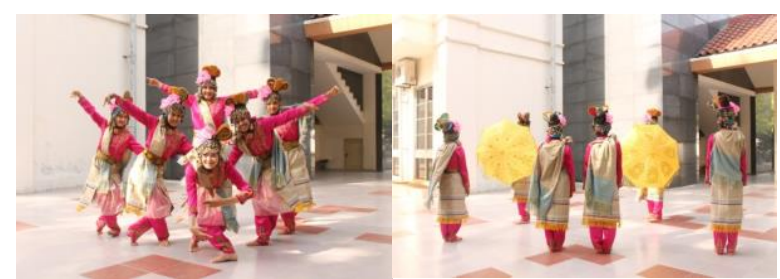

Gambar 8. Busana Penari

(Foto: Novirela Minang Sari, 2014)

\section{Iringan Musik}

Berdasarkan hasil observasi (07 Mei 2014) pukul 16.00 wib bersama Muhammad Ridha selaku ketua dan pemusik sanggar Rampoe bahwa alat musik yang digunakan pada tari kreasi Cangklak yaitu gendrang, rapai, jimbe dan seurune kalee.

\section{PENUTUP}

Bedasarkan hasil penelitian yang telah penulis lakukan di sanggar Rampoe Banda Aceh, maka di sini penulis membuat beberapa kesimpulan sebagai berikut
Tari Cangklak adalah sebuah tari yang hanya mengedepankan sisi pertunjukan semata.Tarian ini ditarikan oleh enam orang wanita yang membawa properti payung, kipas, sapu tangan, serta memakai gelang kaki. Pakaian tari terdiri dari pakaian Aceh yang telah dimodifikasi seperti songket, kipas kepala, kain kerincing hitam, bunga, sanggul, tali pinggang kasab. Iringan tari berupa gendang, rapai, dan seurune kalee.

Pola lantai pada tarian ini lebih cendrung memakai pola lantai bersaf, berjajar dan lingkaran. Tari Cangklak ini mempunyai 36 gerakan, yaitu: gerak masuk, gerak bergantian, gerak tanpa properti, gerak menari di tempat, gerak keluar masuk, gerak kips awal, gerak membuka kipas, gerak membuka kipas, gerak tutup wajah, gerak buka tutup kipas, gerak berhadapan, gerak kipas berhadapan, gerak melingkar, gerak melayu kipas, gerak duduk dan jalan, gerak serong, gerak kipas akhir, gerak meletakkan kipas, gerak masuk kedua, gerak petik jari, gerak mundur, gerak burung, gerak petik, gerak berhadapan, gerak diagonal sejajar, gerak duduk berdiri, gerak lurus sejajar, gerak tepuk tangan, gerak berpasangan, gerak berpandangan, gerak angkat kaki, gerak memainkan sapu tangan, gerak rentang tangan, gerak sejajar, gerak habis, gerak pulang, bersama serta diiringi alat-alat musik tradisional seperti, gendang, seurune kalee, dan rapa-i. Tari Cangklak menggunakan tempo lambat diawal tarian, sedang, dan cepat pada akhir tarian. Tata rias yang digunakan para penari yaitu rias cantik yang disesuaikan dengan warna kostum.

\section{DAFTAR PUSTAKA}

Arikunto, Suharsimi. 2006. Prosedur Penelitian Suatu Pendekatan Praktik. Jakarta: RinekaCipta

Azwardi. 2012. Penelitian. Banda Aceh

Endo. 2006. Tari Tontonan Kesenian Nusantara. Jakarta: Lembaga Pendidikan Seni Nusantara

Depdiknas. (2004). Kebudayaan Daerah Musik dan Tari Daerah Istimewa Aceh, Jakarta: Pusat Penelitian Sejarah Budaya.

Hafnidar, (2004). Wawasan Seni Tari: Pengetahuan Praktis Bagi Guru Seni Tari. Universitas Negeri Malang : Perpustakaan Nasional (KDT).

Yusri Sulaiman. Tari Cangklak, Banda Aceh: No Government Individual 